\title{
Hyponatremia induced by angiotensin converting enzyme inhibitors
}

\author{
B. Raghuveer, Merugu Padma Latha*
}

Department of Pharmacology, Kamineni Institute of Medical Sciences, Narketpally, Nalgonda, Telangana, India

\author{
Received: 01 August 2019 \\ Revised: 20 November 2019 \\ Accepted: 21 November 2019 \\ *Correspondence: \\ Dr. Merugu Padma Latha, \\ Email: drraghuveer2019@gmail.com
}

Copyright: (c) the author(s), publisher and licensee Medip Academy. This is an open-access article distributed under the terms of the Creative Commons Attribution Non-Commercial License, which permits unrestricted non-commercial use, distribution, and reproduction in any medium, provided the original work is properly cited.

\begin{abstract}
Background: Hyponatraemia is commonly associated with disease conditions or as an adverse effect of certain drugs. Angiotensin converting enzyme inhibitor (ACEI) and angiotensin II receptor blockers are drugs that have been commonly prescribed for the treatment of hypertension and cardiac diseases. It has become important to evaluate and investigate the incidence of hyponatremia on consumption of these drugs. The study aims to observe the incidence of the adverse drug reaction-hyponatraemia in hypertensive patients on ACEI therapy.

Methods: The patient's data was collected using proforma following which they were randomized into three groups receiving enalapril, ramipril and captipril. Serum sodium levels were assayed by direct ISE method. Statistical analysis of data was performed using SPSS version 21.0. Chi-square test was used to compare occurrence of hyponatremia in the patients on ACEI. $\mathrm{P}<0.5$ was considered as statistically significant.

Results: Among all, $26(52 \%)$ of the study population administered with ACEI developed hyponatremia. Predisposition to develop hyponatremia was high in males compared to females. The study also revealed that Enalapril had a higher association with hyponatremia compared to other drugs.

Conclusions: Hyponatremia was induced in 52\% of patients taking ACEI. This study revealed that monitoring of serum sodium levels in the patients with ACEI administration will help to prevent unexpected adverse reactions like hyponatremia.
\end{abstract}

Keywords: Angiotensin converting enzyme inhibitors, Hyponatremia, Adverse drug reactions

\section{INTRODUCTION}

The class of drugs called angiotensin converting enzyme (ACE) inhibitors, as the class name suggests, reduce the activity of angiotensin converting enzyme. ACE converts angiotensin I produced by the body to angiotensin II in the blood. Angiotensin II is a very potent chemical that causes the muscles surrounding blood vessels to contract and narrow the blood vessels. Narrowing of blood vessels increases the pressure within the blood vessels and may lead to high blood pressure (hypertension). ${ }^{1}$ By reducing the activity of ACE, ACE inhibitors decrease the formation of angiotensin II which leads to widening (dilation) of blood vessels, and thereby reduces blood pressure. By lowering blood pressure against which the heart must pump, the amount of work that the heart must do is reduced. ACE inhibitors also reduce blood pressure in the kidneys, slowing the progression of kidney disease due to high blood pressure or diabetes. ${ }^{2,3}$ Hyponatremia is defined as a serum sodium concentration below 135 $\mathrm{mmol} / \mathrm{l}$ and may be associated with low, normal (275 to $290 \mathrm{mmol} / \mathrm{kg}$ ) or high osmolality. ${ }^{4}$ Clinical severity is dependent both on the magnitude of the hyponatremia and the rate at which the serum sodium level has declined. When the decrease in serum sodium is marked ( $\leq 125 \mathrm{mmol} / \mathrm{l}$ ) or acute (occurring over $<48 \mathrm{~h}$ ), serious neurological complications can ensue as a result of cerebral oedema. Headache, nausea, vomiting, muscle 
cramps, lethargy, restlessness, disorientation, and depressed reflexes can be observed. Complications of severe and rapidly evolving hyponatremia include seizures, coma, permanent brain damage, respiratory arrest, brain-stem herniation, and death. Diagnosis is based on a detailed clinical history and physical examination, serum and urinary sodium and plasma osmolality. ${ }^{5-7}$ Hyponatraemia is commonly associated with disease conditions or as an adverse effect of certain drugs. With increasing polypharmacy and an ageing population, the prevalence of drug-induced hyponatraemia is likely to increase. ${ }^{8}$ Most patients with drug-induced hyponatraemia are asymptomatic and the diagnosis is made incidentally following routine blood tests. ${ }^{9}$ Angiotensin converting enzyme inhibitor (ACEI) and angiotensin II receptor blockers (ARB) are drugs that have been commonly prescribed for the treatment of hypertension and cardiac diseases. It has become important to evaluate and investigate the incidence of hyponatremia on consumption of these drugs.

\section{METHODS}

\section{Place of study}

This study was placed at Kamineni Institute of Medical Sciences, Narketpally, Nalgonda, Telangana, India.

\section{Type of study}

This was a cross-sectional study.

\section{Sample collection}

Sample size was 50 .

Sampling methods: Consecutive sampling.

\section{Inclusion criteria}

Patients above 18 years, both sex, having ACEI for minimum of one month were included in the study.

\section{Exclusion criteria}

Patients with known renal failure, history of diarrhoea during past one week and intake of additional drugs that have been known to cause hyponatremia were excluded from the study.

\section{Statistical methods}

Statistical analysis of data was performed using SPSS version 21.0. Chi-square test was used to compare occurrence of hyponatremia in the patients on ACEI. $\mathrm{P}<0.5$ was considered as statistically significant.

Serum sodium levels were assayed in patients taking ACEI and ARB; 50 patients were recruited. The patient's age, sex, drug dosage, frequency of the drug administration was collected using a proforma. Statistical analysis of data was performed using SPSS version 21.0.

\section{RESULTS}

\section{Incidence of hyponatremia}

Among all, 52\% (26) of the study population administered with ACEI developed hyponatremia. Predisposition to develop hyponatremia was high in males (70\%) compared to females $(25 \%)$. Incidence of hypoanatremia was more $(60.7 \%)$ in the older age group (56-75 years) compared to the $45-55$ years age group.

Table 1: Incidence of hyponatremia.

\begin{tabular}{|c|c|c|c|c|}
\hline \multirow[b]{2}{*}{ Variable } & \multicolumn{2}{|c|}{ Total no. of subjects } & \multicolumn{2}{|c|}{$\begin{array}{l}\text { Subjects who } \\
\text { developed } \\
\text { hyponatremia }\end{array}$} \\
\hline & $\mathbf{N}(\%)$ & $\begin{array}{l}\text { Mean } \\
\text { sodium } \\
\text { level } \\
(\mathbf{m E q} / \mathbf{l})\end{array}$ & $\mathbf{N}(\%)$ & $\begin{array}{l}\text { Mean } \\
\text { sodium } \\
\text { level } \\
(\mathrm{mEq} / \mathrm{l})\end{array}$ \\
\hline \multicolumn{5}{|l|}{ Gender } \\
\hline Male & $30(60)$ & 133.1 & $21(70)$ & 129.6 \\
\hline Female & $20(40)$ & 135.8 & $5(25)$ & 130.9 \\
\hline \multicolumn{5}{|c|}{ Age (in years) } \\
\hline $45-55$ & $22(44)$ & 135.4 & $8(36)$ & 130.2 \\
\hline $55-65$ & $14(28)$ & 132.8 & $9(65)$ & 130.5 \\
\hline$>65$ & $14(28)$ & 135.2 & $8(57)$ & 129.6 \\
\hline Total & $50(100)$ & 136.0 & $26(52)$ & 130.3 \\
\hline
\end{tabular}

\section{Hyponatremia induced by individual drugs}

$10(63 \%)$ subjects who were prescribed enalapril developed hyponatremia, whereas $14(50 \%)$ and 1 (17\%) subjects who were prescribed ramipril and captopril respectively developed hyponatremia.

Table 2: Hyponatremia induced by individual drugs.

\begin{tabular}{|lll|}
\hline Drug & $\begin{array}{l}\text { Total no. of } \\
\text { subjects }\end{array}$ & $\begin{array}{l}\text { Subjects who developed } \\
\text { hyponatremia }(\%)\end{array}$ \\
\hline Enalapril & 16 & $10(63)$ \\
\hline Ramipril & 28 & $14(50)$ \\
\hline Captipril & 6 & $1(17)$ \\
\hline
\end{tabular}

\section{DISCUSSION}

Drug induced hyponatraemia is commonly associated with diuretics, selective serotonin reuptake inhibitors and antiepileptics. With increasing polypharmacy and an aging population, the prevalence of drug induced hyponatraemia is likely to increase. Angiotensin converting enzyme inhibitors are a group of vasodilators which are frequently used for the treatment of hypertension and congestive cardiac failure. They have been found to cause significant hyponatraemia 
occasionally, alone or in combination with diuretics or salt restriction. Approximately 20 cases of severe hyponatraemia with ACE inhibitors have been reported in literature. ACE inhibitors in antihypertensive doses may block conversion of angiotensin I to angiotensin II in the peripheral circulation but not in the brain. Increased circulating angiotensin I enters the brain and is converted to angiotensin II, which may stimulate thirst and release of $\mathrm{ADH}$ from the hypothalamus, eventually leading to hyponatraemia. The present study revealed the occurrence of hyponatremia in $52 \%$ of the participants on ACEI (Table 1). This finding coincides with more incidence of hyponatremia with the case reports on ACEI induced hyponatremia. $^{10} \mathrm{~A}$ previous study on losartan had reported higher susceptibility of females to hyponatremia compared to men. ${ }^{11}$ However, the present study results indicate higher susceptibility of males compared to females. Incidence of hyponatremia was high in the age group 56-75 years compared to the lower age groups (4455 years). However, the magnitude of serum sodium lowering was found to be higher in patients above 66 years of age. These results coincide with those of similar studies. ${ }^{12,13}$ Assessment and management of a patient with hyponatraemia depends on the clinical status and the likelihood that one or more drugs are responsible. Most hyponatraemic patients would be asymptomatic. Patients with moderate to severe hyponatraemia may present with symptoms like anorexia, nausea, restlessness, muscle weakness, spasm or cramps, confusion, irritability, convulsions and coma. Alternative explanations for these clinical features should always be considered. Conditions which may be responsible for hyponatraemia like cardiac, liver and renal failure should be ruled out. ${ }^{14}$ A careful history, examination and clinical assessment of fluid status are needed to exclude non drug causes of hyponatraemia. Raised blood sugar or urea level, pseudohyponatraemia due to hypertriglyceridaemia and paraproteinaemia and other occult co-morbidities like hypothyroidism and hypoadrenalism should be excluded. $^{15}$ Syndrome of inappropriate anti diuretic harmone due to some malignancy or central nervous system lesion should also be looked for. In mild to moderate cases of ACE inhibitors induced hyponatraemia or drug induced hyponatraemia with a normovolaemic fluid status clinically, ceasing the offending drug and gentle fluid restriction would improve serum sodium levels gradually within a week. ${ }^{16,17}$ In an acutely unwell patient due to severe drug induced hyponatraemia, severe fluid restriction or infusion of hypertonic saline may be required. ACE inhibitors have some potassium retaining properties but serum potassium level usually remains within normal limits when an ACE inhibitor is used alone. ${ }^{18,19}$ Patients may show hypokalaemia if thiazide or loop diuretics are used concomitantly with ACE inhibitors.

\section{CONCLUSION}

Among all, 26 (52\%) of the study population administered with ACEI developed hyponatremia. This study revealed that monitoring of serum sodium levels in the patients with ACEI administration will help to prevent unexpected adverse reactions like hyponatremia.

\section{Funding: No funding sources \\ Conflict of interest: None declared}

Ethical approval: The study was approved by the Institutional Ethics Committee

\section{REFERENCES}

1. Miller M, Morley JE, Rubenstein LZ. Hyponatraemia in a nursing home population. J Am Geriatr Soc. 1995;43:1410-3.

2. Arieff AI, Llach F, Massry SG. Neurological manifestations and morbidity of hyponatraemia: correlation with brain water and electrolytes. Medicine (Baltimore). 1996;55:121-9.

3. Arieff AI. Hyponatraemia, convulsions, respiratory arrest, and permanent brain damage after elective surgery in healthy women. $\mathrm{N}$ Eng $\mathrm{J}$ Med. 1986;314:1529-35.

4. Riquelme A, Mendez F, Ortiz AM. Severe and recent hyponatraemia and hypokalemia associated to the use of hydrochlorothiazide, enalapril and citalopram. Clinical case. Rev Med Chil. 1999;127(10):1223-8.

5. Christensen O, Sorensen HA, Almdal TP. Adverse effects of selective serotonin inhibitors. Hyponatraemia caused by Schwartz-Bartter syndrome. Ugesker Laeger. 1996;158(48):6920-2.

6. Hess B, Keusch G, Neftel K, Bansky G. Severe electrolyte disorders during therapy of heart failure with ACE inhibitor enalapril. Schweiz Med Wochenschr. 1986;116(39):1331-6.

7. Gonzalez-Martinez H, Gaspard JJ, Espino DV. Hyponatraemia due to enalapril in elderly patient. Arch Fam Med 1993;2(7):791-3.

8. Subramanian D, Ayus JC. Case report. Severe symptomatic hyponatraemia associated with lisinopril therapy. Am J Med Sci. 1992;303(3):177-9.

9. Al-Mufti HI, Arieff AI. Captopril-induced hyponatremia with irreversible neurologic damage. Am J Med. 1985;79(6):769-71.

10. Kinoshita H, Kobayashi K, Yaguramaki T, Yasuda M, Fujiki K, Tomiyama J, et al. Losartan potassium/hydrochlorothiazide (Preminent ${ }^{\circledR}$ ) and hyponatremia: Case series of 40 patients. Human Exp Toxicol. 2011;30(9):1409-14.

11. Tilly Gentric A. Severe hyponatremia associated with ramipril therapy in an old woman. J Am Geriatr Society. 1995;43(12):1448-79.

12. Castrillon JL, Mediavilla A, Mendez MA, Cavada E, Carrascosa M, Valle R. Syndrome of Inappropriate Antidiuretic Hormone Secretion (SIADH) and enalapril. J Internal Med. 1993;233(1):89-91.

13. Chakithandy S, Evans R, Vyakarnam P. Acute severe hyponatraemia and seizures associated with postoperative enalapril administration. Anaesth Intensive Care. 2009;37(4):673-74. 
14. Goto Y, Wakita S, Yoshimitsu M, Inagaki S, Kobayashi T, Kaneko S. Onset of syndrome of inappropriate secretion of antidiuretic hormone in a gastric cancer patient on SOX treatment. Gan To Kagaku Ryoho. 2015;42(13):2467-70.

15. Abramow M, Cogan E. Clinical aspects and pathophysiology of diuretic-induced hyponatremia. Adv Nephrol Necker Hosp. 1984;13:1-28.

16. Clark BA, Shannon RP, Rosa RM, Epstein FH. Increased susceptibility to thiazide-induced hyponatremia in the elderly. J Am Soc Nephrol 1994;5:1106-11.

17. Pinnock CA. Hyponatraemia associated with hydrochrorothiazide treatment. Br Med J. 1978;1:4854.
18. Dyckner T, Wester PO. Effects of magnesium infusions in diuretic induced hyponatraemia. Lancet 1981;1(8220):585-6.

19. Chapman M, Hanrahan R, McEwen J, Marley J. Hyponatremia and hypokalemia due to indapamide. MJA. 2002;176:219-21.

Cite this article as: Raghuveer B, Latha MP. Hyponatremia induced by angiotensin converting enzyme inhibitors. Int J Basic Clin Pharmacol 2020;9:81-4. 